\title{
Molecular organization of 5S rDNA in fishes of the genus Brycon
}

\author{
Adriane Pinto Wasko, Cesar Martins, J onathan M. Wright, and \\ Pedro Manoel Galetti, J r.
}

\begin{abstract}
There are few reports on the genomic organization of 5S rDNA in fish species. To characterize the 5S rDNA nucleotide sequence and chromosomal localization in the Neotropical fishes of the genus Brycon, 5S rDNA copies from seven species were generated by PCR. The nucleotide sequences of the coding region (5S rRNA gene) and the nontranscribed spacer (NTS) were determined, revealing that the 5S rRNA genes were highly conserved, while the NTSs were widely variable among the species analyzed. Moreover, two classes of NTS were detected in each species, characterized by base substitutions and insertions-deletions. Using fluorescence in situ hybridization (FISH), two 5S rDNA chromosome loci that could be related to the two 5S rDNA NTS classes were observed in at least one of the species studied. 5S rDNA sequencing and chromosomal localization permitted the characterization of Brycon spp. and suggest a higher similarity among some of them. The data obtained indicate that the 5S rDNA can be an useful genetic marker for species identification and evolutionary studies.
\end{abstract}

Key words: Brycon, FISH, nontranscribed spacer, nucleotide sequence, 5S rDNA.

Résumé : Il y a peu de travaux rapportés sur l'organisation génomique de l'ADNr 5S chez les poissons. Afin de caractériser la séquence nucléotidique et la localisation chromosomique de l'ADNr 5S chez des poissons néotropicaux du genre Brycon, des copies de l'ADNr 5S ont été obtenues par PCR chez sept espèces. La séquence nucléotidique de la région codante (gène d'ARNr 5S) et de l'espaceur non-transcrit (NTS) a été déterminée. Ces travaux ont révélé que les gènes d'ARNr $5 \mathrm{~S}$ étaient très conservés tandis que les régions NTS étaient très variables parmi les espèces analysées. De plus, deux classes de NTS ont été détectées chez chacune des espèces et ces séquences se distinguaient en raison de substitutions nucléotidiques et d'insertions-délétions. Deux locus chromosomiques d'ADNr 5S ont été observés par hybridation in situ en fluorescence (FISH) chez au moins une des espèces étudiées, ce qui pourrait être lié à la présence de deux classes de NTS. Le séquençage et la localisation de l'ADNr $5 \mathrm{~S}$ ont permis de caractériser les espèces du genre Brycon et suggèrent une plus grande similarité entre certaines espèces. Les données obtenues montrent que l'ADNr 5S peut être un marqueur génétique utile pour des fins d'identification des espèces et pour des études de l'évolution.

Mots clés : Brycon, FISH, espaceur non-transcrit, séquence nucléotidique, ADNr 5S.

[Traduit par la Rédaction]

\section{Introduction}

Ribosomal DNA (rDNA) is organized in higher eukaryotes into two distinct gene classes composed of tandemly repeated units of hundreds to thousands of copies. The major class (45S rDNA) comprises the $18 \mathrm{~S}, 5.8 \mathrm{~S}$, and $28 \mathrm{~S}$ rRNA genes, and is related to the nucleolar organizer

Received January 27, 2001. Accepted May 16, 2001.

Published on the NRC Research Press Web site at

http://genome.nrc.ca on September 7, 2001.

Corresponding Editor: W. Traut.

A.P. Wasko ${ }^{1}$ and C. Martins. Departamento de Morfologia, Instituto de Biociências, Universidade Estadual Paulista, Botucatu, São Paulo 18618-000, Brazil.

J.M. Wright. Department of Biology, Dalhousie University, Halifax, NS B3H 4H6, Canada.

P.M. Galetti, Jr. Departamento de Genética e Evolução, Universidade Federal de São Carlos, São Carlos, São Paulo 13565-905, Brazil.

${ }^{1}$ Corresponding author (e-mail: awasko@ibb.unesp.br). regions (NORs), and the minor class (5S rDNA) is represented by the $5 \mathrm{~S}$ rRNA gene family. The $5 \mathrm{~S}$ rDNA repeats consist of a highly conserved coding sequence of $120 \mathrm{bp}$ and a nontranscribed flanking DNA (nontranscribed spacer; NTS) (reviewed in Long and David 1980). Variations in the NTS, related to insertions-deletions, minirepeats, and pseudogenes, are often species specific and have been successfully used in evolutionary studies (Nelson and Honda 1985; Leah et al. 1990; Sajdak et al. 1998). In addition, the chromosomal localization of the 5S rDNA has been reported for some animals, including fish (Pendás et al. 1994; Móran et al. 1996; Fujiwara et al. 1998; Murakami and Fujitani 1998; Sajdak et al. 1998; Martins et al. 2000), although few analyses have been performed in Neotropical species (Martins and Galetti 1999, 2000, 2001; Born and Bertollo 2000).

Fishes of the genus Brycon have been reported for all main hydrographic Brazilian systems and represent important fishery resources and (or) hatchery stocks in some areas. However, human activities have threatened or led to the extinction of some populations (Braga 1982), and conservation actions in the wild are badly needed. Moreover, little is 
Table 1. Description of Brycon spp. analyzed.

\begin{tabular}{|c|c|c|c|c|c|c|}
\hline \multirow[b]{2}{*}{ Species } & \multirow[b]{2}{*}{ Collection site } & \multirow[b]{2}{*}{ Clones } & \multicolumn{3}{|c|}{ Length (bp) } & \multirow[b]{2}{*}{ GenBank No } \\
\hline & & & Gene & NTS & $5 \mathrm{~S}$ repeat & \\
\hline \multirow[t]{6}{*}{ B. lundii } & \multirow[t]{6}{*}{ São Francisco River (Township of Três Marias, Minas Gerais State) } & B1 $122(1)$ & 120 & 123 & 243 & AF250513 \\
\hline & & B1 $125(1)$ & 120 & 122 & 242 & AF250514 \\
\hline & & B1 $124(1)$ & 120 & 123 & 243 & AF250515 \\
\hline & & B1 $51(1)$ & 120 & 123 & 243 & AF250516 \\
\hline & & B1 $52(2)$ & 120 & 108 & 228 & AF250511 \\
\hline & & B1 $56(2)$ & 120 & 108 & 228 & AF250512 \\
\hline \multirow[t]{4}{*}{ B. orbignyanus } & \multirow[t]{4}{*}{ Paraná River (Township of Porto Rico, Paraná State) } & Bo 2 (1) & 120 & 120 & 240 & AF250519 \\
\hline & & Bo 5 (1) & 120 & 121 & 241 & AF250520 \\
\hline & & Bo 3 (2) & 120 & 106 & 226 & AF250517 \\
\hline & & Bo 4 (2) & 120 & 106 & 226 & AF250518 \\
\hline \multirow[t]{7}{*}{ B. microlepis } & \multirow[t]{7}{*}{ Cuiabá River (Township of Cuiabá, Mato Grosso State) } & Bm $12(1)$ & 120 & 120 & 240 & AF250521 \\
\hline & & Bm 18 (1) & 120 & 120 & 240 & AF250522 \\
\hline & & $\mathrm{Bm} 4$ (1) & 120 & 120 & 240 & AF250523 \\
\hline & & Bm 16 (1) & 120 & 120 & 240 & AF250524 \\
\hline & & Bm 15 (1) & 120 & 120 & 240 & AF250525 \\
\hline & & Bm 13 (2) & 120 & 104 & 224 & AF250526 \\
\hline & & Bm 14 (2) & 120 & 104 & 224 & AF250527 \\
\hline \multirow[t]{5}{*}{ B. cephalus } & \multirow[t]{5}{*}{ Amazonas River (Township of Manaus, Amazonas State) } & Bc 13 & 120 & 227 & 347 & AF250530 \\
\hline & & Bc 12 (2) & 120 & 229 & 349 & AF250531 \\
\hline & & $\mathrm{Bc} 15$ (2) & 120 & 227 & 347 & AF250532 \\
\hline & & $\mathrm{Bc} 14$ (d) & 120 & 232 & 352 & AF250528 \\
\hline & & $\mathrm{Bc} 33$ (d) & 120 & 232 & 352 & AF250529 \\
\hline \multirow[t]{4}{*}{ Brycon sp. } & \multirow[t]{4}{*}{ Araguaia River (Township of Aragarças, Goiás State) } & Bsp $3(2)$ & 120 & 220 & 340 & AF250533 \\
\hline & & Bsp $7(2)$ & 120 & 221 & 341 & AF250534 \\
\hline & & Bsp $11(2)$ & 120 & 221 & 341 & AF250535 \\
\hline & & Bsp $17(d)$ & 120 & $222-223$ & $342-343$ & AF250536 \\
\hline \multirow[t]{5}{*}{ B. brevicauda } & \multirow[t]{5}{*}{ Araguaia River (Township of Aragarças, Goiás State) } & $\mathrm{Bb} 6(1)$ & 120 & 119 & 239 & AF250537 \\
\hline & & $\mathrm{Bb} 12(1)$ & 120 & 117 & 237 & AF250538 \\
\hline & & $\mathrm{Bb} 5(1)$ & 120 & 118 & 238 & AF250539 \\
\hline & & $\mathrm{Bb} 1(2)$ & 120 & 677 & 797 & AF250540 \\
\hline & & $\mathrm{Bb} 13(2)$ & 120 & 678 & 798 & AF250541 \\
\hline \multirow[t]{5}{*}{ B. insignis } & \multirow[t]{5}{*}{ Paraíba do Sul River (Township of Pindamonhangaba, São Paulo State) } & Bi 2 (1) & 120 & 115 & 235 & AF250545 \\
\hline & & Bi $8(1)$ & 120 & 115 & 235 & AF250546 \\
\hline & & Bi $13(2)$ & 120 & 391 & 511 & AF250542 \\
\hline & & Bi 14 (2) & 120 & 391 & 511 & AF250543 \\
\hline & & Bi 15 (2) & 120 & 391 & 511 & AF250544 \\
\hline
\end{tabular}


Fig. 1. PCR-generated 5S rDNA products obtained from $B$. lundii (lane 1), B. orbignyanus (2), B. microlepis (3), B. cephalus (4), Brycon sp. (5), B. brevicauda (6), and B. insignis (7). Lane $\mathrm{M}$ is a 100-bp molecular weight ladder.

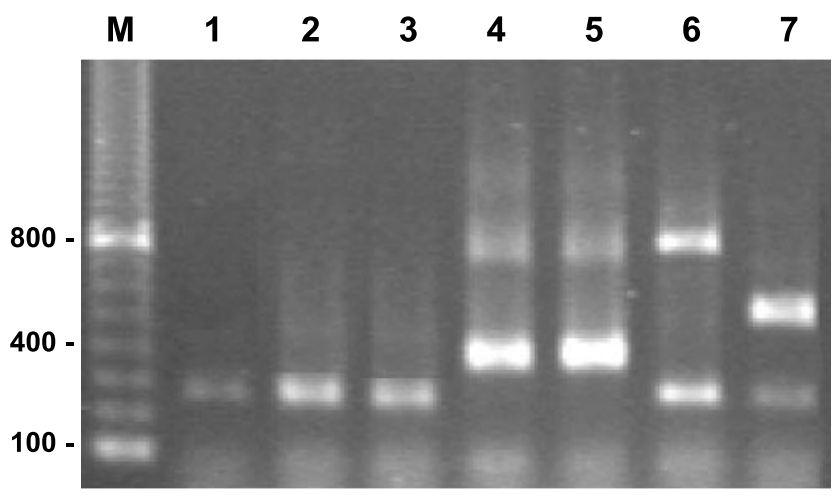

known of the genetics of this fish group, which is considered to be a monophyletic unit with about 40 species (Howes 1982). As part of an ongoing effort to characterize species of the genus Brycon and to examine relationships among them, the 5S rDNA nucleotide sequence and chromosomal localization were analyzed in seven species of the group. To address this issue, PCR-generated 5S rDNA repeats were cloned, sequenced, and used as probes in chromosomal fluorescence in situ hybridization (FISH).

\section{Materials and methods}

\section{PCR}

Seven species of the genus Brycon from different Brazilian river systems were studied (Table 1). Genomic DNA was extracted from the liver according to the phenol-chloroform method detailed in Sambrook et al. (1989). A set of primers corresponding to nucleotides 24-44 (primer A, 5'-TACGCCCGATCTCGTCCGATC-3') and nucleotides 1-21 (primer B, 5'-CAGGCTGGTATGGCCGTAAGC$3^{\prime}$ ) of the $5 \mathrm{~S}$ coding region were designed from the $5 \mathrm{~S}$ rDNA sequence of rainbow trout (Komiya and Takemura 1979), to amplify the 5S rRNA genes and their NTS regions (Pendás et al. 1994; Martins and Galetti 1999). PCR amplifications were carried out in a total volume of $50 \mu \mathrm{L}$ containing $50 \mathrm{ng}$ of genomic template DNA, 150 pmol of each primer, $1.25 \mathrm{mM}$ of each dNTP, PCR buffer containing $1.5 \mathrm{mM} \mathrm{MgCl}_{2}$, and $1 \mathrm{U}$ of Taq DNA polymerase (Pharmacia.Biotech), using a Perkin Elmer 2400 thermocycler. The optimum cycling times were as follows: $5 \mathrm{~min}$ at $94^{\circ} \mathrm{C}$ (denaturation); 35 cycles of $1 \mathrm{~min}$ at $95^{\circ} \mathrm{C}, 30 \mathrm{~s}$ at $63^{\circ} \mathrm{C}$, and $1 \mathrm{~min}$ at $72^{\circ} \mathrm{C}$ (amplification); and a final $7 \mathrm{~min}$ at $72^{\circ} \mathrm{C}$ (extension). The $5 \mathrm{~S}$ rDNA-PCR products were visualized by ethidium bromide staining of a $1.5 \%$ agarose gel.

\section{Cloning and sequencing}

The PCR products were cloned in the plasmids pGEM-T or pGEM-T Easy (Promega) and used to transform competent cells of Escherichia coli strain DH5 $\alpha$ (GibcoBRL). A total of 36 clones were sequenced on a LICOR 4200 automatic sequencer with a T7 Sequenase 7-deza-dGTP sequencing kit (Amersham); sequence alignment was performed using Clustal W (Thompson et al. 1994). Nucleic acid sequences were subjected to BLASTN (Altschul et al. 1990) searches at the National Center for Biotechnology Information (NCBI), web site (http://www.ncbi.nlm.nih.gov/blast).

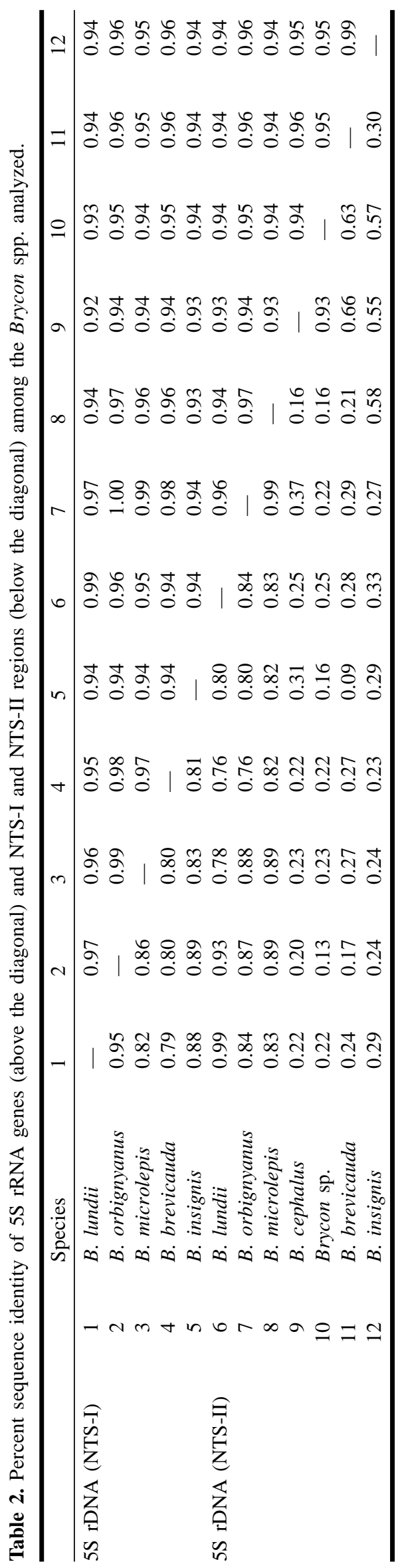

(C) 2001 NRC Canada 
Fig. 2. Alignment of $5 \mathrm{~S}$ rDNA consensus sequences of B. lundii (a), B. orbignyanus (b), B. microlepis (c), B. cephalus $(d)$, Brycon sp. $(e)$, B. brevicauda $(f)$, and $B$. insignis $(g)$. The coding sequence of the $5 \mathrm{~S}$ rDNA is in boldface type and the primers used to amplify the 5S rDNA are underlined. Hyphens indicate gaps. Base substitutions are indicated in red letters. TATA-like elements are indicated in blue and a conserved $5^{\prime}$-NTS region is shown in green.

(a)

NTS-I

NTS-II

NTS-I

NTS-II

NTS-I

NTS-II

(b) NTS-I NTS-II

NTS-I NTS-II

NTS-I

NTS-II

(c) NTS-I

NTS-II

NTS-I

NTS-II

NTS-I

NTS-II

(d)

NTS-II

(a)

TACGCCCGATCTCGTCCGATCTCGGAAGCTAACCAAGGTCGGGCCTGGTTAGTACTTGGATGGGAAACTGCCTGGGAATACCAGGTGCTGTA GCTTTTTT CCAACCTGAAGCACTTACATGCACGTACATTCAGTTCAGTGTCTTTACTTTGTTTTACTCCATCTCATTTTATGTTTTCAGAAAT GTACAAGAGATTACACTATAGTTTTATATACATCACTGTATTACATTTCATACAGCCTTTGGAGTCTTGAGAGTGAAAAAAAATGTAGATACC 349 CTTTGAAAAGCTTTGCATTTATAAATAGGCTCTCTGGAGCAGTGCTCTAGCTTACGGCCATACCAGCCTG

(e) NTS-II

(f) NTS-I NTS-II

NTS-I NTS-II

NTS-I NTS-II

NTS-I NTS-II

NTS-I NTS-II

TACGCCCGATCTCGTCCGATCTCGGAAACAAAGCAGGGTCTGGCCTGATTAGTACTTGGATGGGAGACTGCTTGGGAATACCAGGTGCCGI TACGCCCGATCTCGTCCGATCTCGGAAACAAAGCAGGTCTGGCCTGATTAGTACTTGGATGGGAGACTGCTTGGGAATACCAGGTGCTGTAA

GCTTT CCAACCCGGCAAACAATCGAAGGTTGAATTTGCTTTATATCTT"TTTGCTTTATAGCTTACATT"TGCTTCATTTTGTTTATTTTTTTT GCTT TTCCAACCCGGCAAACAATCGAAGGTTGAATTTGCTTTATA-_-_-_-_-_GCTTACATTTGCTTCATTTTGTTTATTTTTTTT 243

CATTTCCTTTATACTCTGATACTCAACGAAGCTTCT GCTTACGGCCATACCAGCCTG CATTTCCTTTATACTCTGATACTCAACGAAGCTTCT GCTTACGGCCATACCAGCCTG

TACGCCCGATCTCGTCCGATCTCGGAAGCAAAGCAGGGTCGGGCTTATTAGTACTTGGATGGGAGACTGCCTGGGAATACCAGGTGCCGTAA TACGCCCGATCTCGTCCGATCTCGGAAGCAAAGCAGGGTCGGCCTGATTAGTACTTGGATGGGAGACTGCCTGGGAATACCAGGTGCCGTAA

GCTTTCCAACCCTGCAAACAATCGAAGGTTGAATTTGCTTTATATCTTTTTGCTTTATAGCTTACATTTGCTTTATTTTTTATTTTTTTTCA GCTTT TCAACCCTGCAAACAATCGAAGGTTGCATTTGCTTTATA-----------GCTTACATTGGCTTAATTTTTTATTTTTTTTCA 241

TTTCCTTTATACTCTGCTTCTCAAAGAAGCTTCTGCTTACGGCCATACCAGCCTG

TTTGCTTTATACTCTGCTTCTCAAACT GTTTTTA ACTTACGGCCATACCAGCCTG

TACGCCCGATCTCGTCCGATCTCGGAAGCAAAGCAGGGTCGGGCTTATTAGTACTTGGATGGGAGACTGGCTGGGAATACCAGGTGCCGTAA TACGCCCGATCTCGTCCGATCTCGGAAGCCAAGCAGAGTCGGGCCTGATTAGTACTTGGATGGGAGACTGCCTAGGAATACCAGGTGCCGTAA

GCTTT GCTT TICCAACCCTGCAAACAATCGAAGGTTGCATTTGCTTTATA-_-_-_._-_TCACATTGGCTTTATTT TT TTTTTTTTTCAT 240

TTGCTTTTTACTCTACTTCTCAAAATATTTTTAGCTTACGGCCATACCAGCCTG

TTGCTTTATACTCTGCTTCTCAAA-TGTTTTTA 79

93

TACGCCCGATCTCGTCCGATCTCGGAAGCTAAGCAGGGTTGGGCTGATTAGTACTTTGAAGGGAGACTGCCTGGGAATACCAGGTGCTGTAA GCTTTTTTCCAACCTGAAGCACTTTCATGCACGTACATTCAGTTCAGTGTCTTTACTTTGTTTTACTCCATCTCATTTTATGTTTTCAGAAAT $\begin{array}{r}279 \\ \hline T \text { С }\end{array}$ GTACACGAGATTACACTATAGTTTTATATACATCACTGTATTACATATCATACAGCTTTGGAGCTGAGAGTGAAAATGTGAAAATGCAGACAC 341 CTTTGAAACTTTGCATTATATAGCTATCTGGAGCATATCTCGCTTACGGCCATACCAGCCTG

93 TACGCCCGATCTCGTCCGATCTCGGAAGCTAAGCAGGGTCGGGCCTGATTAGTACTTGGATGGGAGACTTCCTGGGAATACCAGGTGCCGTAA TACGCCCGATCTCGTCCGATCTCGGAAGCTAAGCAGGGTCGGGCCTGGTTAGTACTTGGATGGGAGACCGCCTGGGAATACCAGGTGCTGTAA

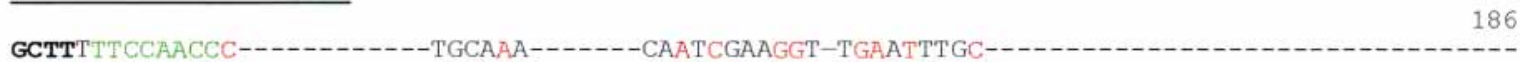
GCTTTTTCCAACCTCACGCACGTACATGCACATTTTTTTCAGTT GAATCTCTTTACTTTGTTTTACTCCACCTAACTTTCTGTTTTCACAAAT 279 GTACAAGAGATGACACTAGAGTTT TATATACATCACTGTATTACATTTCACACAGCCTTTGGAGTCTTGAGAGTGAAAACATATGAGCGTCAG GTACAAGAGATGACACTAGAGTT CTGCGCTTTAAACCCACCTGCCTGGCCTGCCATGTCATGTGAATGAATAAATTGTACTTAGGCTTAATTCCATTTAATTTCTCTGAAAACAAA

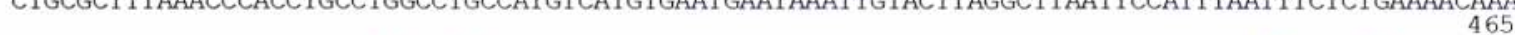
ACACAGAAACATACAGTGCAATCATTTGTATGAAAGGAATGCTGAGAATAAAAATACCTGAAGCCTGCCAGTAGCTTGCCAGTACTTT"TCACA 
Fig. 2 (concluded).

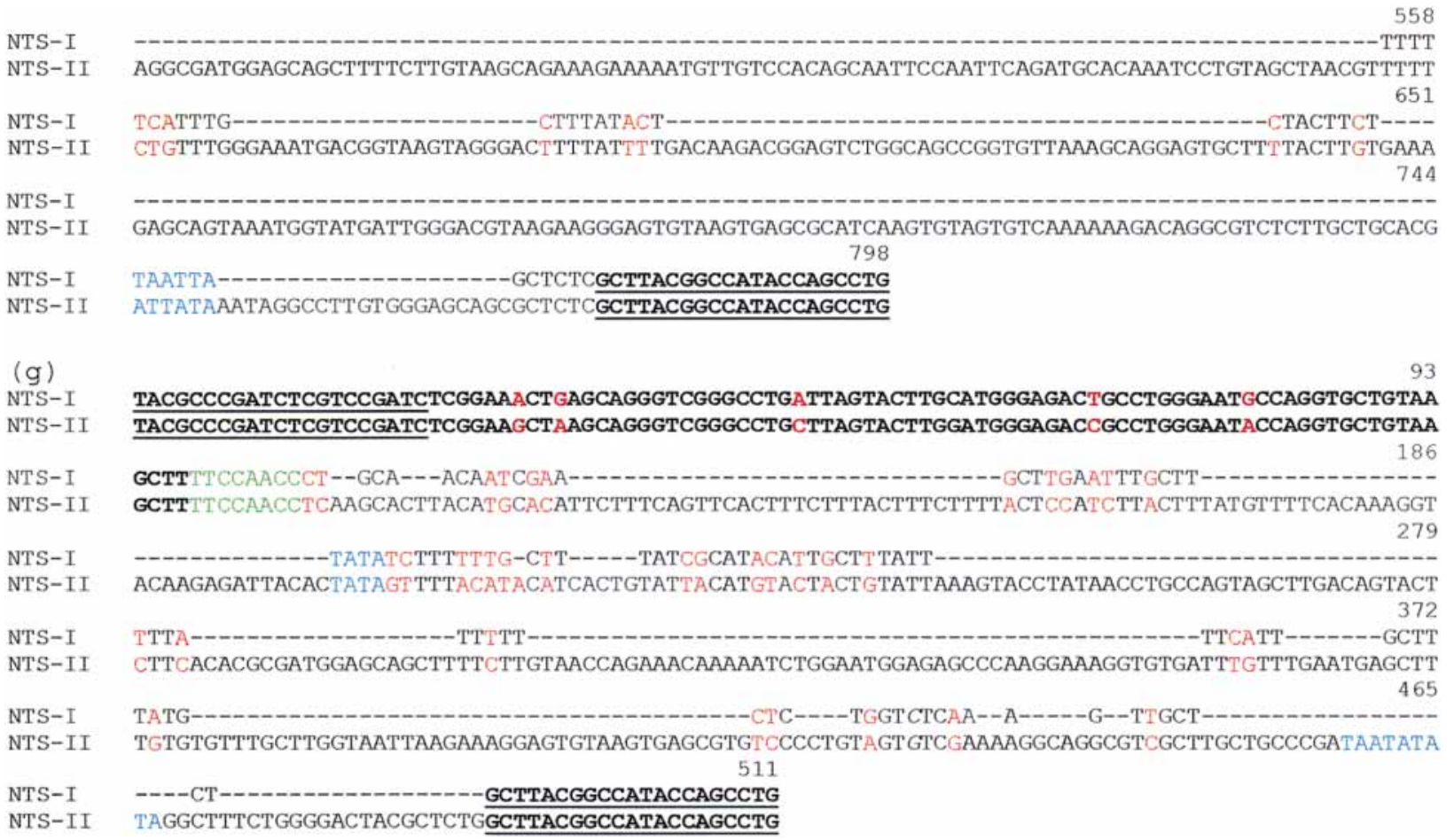

\section{Chromosomal localization}

Mitotic chromosomes were obtained from suspensions of anterior kidney cells using a conventional air-drying technique (Bertollo et al. 1978) and short-term solid tissue culture (Fenocchio et al. 1991). FISH was performed as detailed in Wasko and Galetti (2000), using a PCR-generated 5S rDNA of B. lundii as a probe (labeled by nick translation with biotin-dATP; Bionick ${ }^{\mathrm{TM}}$ Labeling System; GibcoBRL).

\section{Results and discussion}

PCR amplification of 5S rDNA in seven Brycon spp. generated distinct agarose gel electrophoresis band patterns among some species: a band of approximately $250 \mathrm{bp}$ for $B$. lundii, B. orbignyanus, and B. microlepis, two bands of about 350 and 700 bp for B. cephalus and Brycon sp., two bands of about 250 and 800 bp for B. brevicauda, and two bands of approximately 250 and $500 \mathrm{bp}$ for $B$. insignis (Fig. 1). Sequencing analyses showed that $B$. lundii, $B$. orbignyanus, and $B$. microlepis presented two similarly sized 5S PCR products of 224-228 and 240-243 bp that were not distinguishable in agarose gel where they were seen as a single band of about $250 \mathrm{bp}$.

After cloning and sequencing the PCR fragments of each species, a highly conserved region that corresponded to the $5 \mathrm{~S}$ rRNA gene was identified which had an average sequence identity of $95 \%$ among Brycon spp. (Table 2). Some of the few observed differences, related to base substitutions, may be the result of nucleotide misincorporation by Taq DNA polymerase, as the $\mathrm{dNTP}$ and $\mathrm{MgCl}_{2}$ concentrations used in the amplification reactions could lead to a cumulative error frequency of about $0.25 \%$ after 30 PCR cycles (Saiki et al. 1988). Searches using the BLASTN program at NCBI (Altschul et al. 1990) detected a low divergence among the 5S rRNA gene sequences of Brycon spp. and many other vertebrates (average similarity of $88.8 \%$ ), including the fishes Salmo salar (Pendás et al. 1994), Oncorhynchus mykiss (Móran et al. 1996), genus Coregonus (Sajdak et al. 1998), Oreochromis niloticus (Martins et al. 2000), and several species of Leporinus (Martins and Galetti 2001). The 5S rDNA NTSs, however, were highly variable and species specific, and no sequence correspondence was seen between the NTSs of Brycon spp. and those of other fishes, suggesting that this spacer region evolves rapidly. The NTS regions are presumed to be free to vary, since these variants are selectively neutral or nearly neutral and can become either fixed or lost, thereby causing differences. In contrast, most mutations in the $5 \mathrm{~S}$ rRNA gene are presumed to be selectively neutral or nearly neutral only when they occur in subcritical proportion (Cronn et al. 1996).

Two distinct NTS classes, named NTS-I and NTS-II, were detected in $B$. lundii, $B$. orbignyanus, $B$. microlepis, $B$. brevicauda, and $B$. insignis that were characterized by insertions-deletions and base substitutions (Table 1; Fig. 2). In B. cephalus and Brycon sp., two different-sized fragments (approximately 350 and $700 \mathrm{bp}$ ) were visualized by agarose electrophoresis (Fig. 1) but they represented a monomeric and a dimeric 5S rDNA unit. Although only one NTS class was detected in B. cephalus and Brycon sp., it is possible that these two species also have two distinct NTS regions that are yet to be identified. The 5S rDNA monomers of B. cephalus and Brycon sp. could belong to the NTS-II class, as they have a very distinct size and several nucleotide differences. In contrast, NTS-I sequences were very similar among the species, with a mean identity of $84 \%$ (Table 2). Figure 2 presents the alignment of the consensus sequences of the two different 5S rDNA unit size classes of the species studied. Different clones of each species (Table 1) were used to establish the consensus sequences. The sequence 
Fig. 3. Dimeric 5S rDNA tandem arrays from B. cephalus $(a)$ and Brycon sp. $(b)$. The coding sequence of the $5 \mathrm{~S}$ rDNA is in boldface type and the primers used to amplify the 5S rDNA are underlined.

$\downarrow 3^{\prime}$ end

of $5 \mathrm{~S}$ rRNA gene 102 TACGCCCGATCTCGTCCGATCTTGGAAGCTAAGCAGGGTCGGGCCTGGTTAGTACTTGGATGGGAGACTGCTGGGAATACCAGGTGCCGTGAGCTTTTTTCC 204 AACCTGAAGCACATTCATGCACGTACATTCAGTTCAGTGTCTTTACTTTGTTTTACTCCATCTCATTTTATGTTTTCAGAAATGTACAAGAGATTACACTAT AGTTTTATATACATCACTGTATTACATTTCATACAGCCTTTGGAGTCTTGCGAGTGAAAAAAAATGTAGATACCCTTTGAAAACCTTTGCATTTATAAATAG 408 GCTCTCTGGAAGCAGTGCTCTCGCTTACGGCCATACCAGCCTGAGAACGCCCGATCTCGTCCGATCTTGGAAGCTAAGCAGGTCGGGCCTGGTTAGTACTT GGATGGGAGACTGCCTGGGAATACCAGGTGCCGTGAGCTTTTTTCCAACCTGAAGCACTTACATGCACGTACATTCAGTTCAGTGTCTTTACTTTGTTTTAC AAAAAAAATGTAGATCCCCTTTGAAAACCTTTGCATTTATAAATAGGCTCTCTGGAAGCAGTGCTCTCGCTTACGGCCATACCAGCCTG AAAAAAAATGTAGATCCCCTTTGAAAACCTTTGCATTTATAAATAGGCTCTCTGGAAGCAGTGCTCTCGCTTACGGCCATACCAGCCTG $\downarrow 3^{\prime}$ end of $5 \mathrm{~S}$ rRNA gene 102 TACGCCCGATCTCGTCCGATCTCGGAAGCTAAGCAGGGTTGGGCCTGATTAGTACTTTGAAGGGAGACTGCCTGGGAATACCAGGTGCTGTAAGCTTTTTTC 204 CAACCTGAAGCACTTTCATGCACGTACATTCAGTTCAGTGTCTTTACTTTGTTTTACTCCATCCCATTTTATGTTTTCAGAAATGTACAAGAGATTACACTA TAGTTTTATATACATCACTGTATTACATATCATACAGCTTTGGAGCTGAGAGTGAAAATGTGAAAATGCAGACACCTTTGAAACTTTGCATTATATAGCTCT 408 CTGGAGCATATCTCGCTTACGGCCATACCAGCCTGAGTACGCCCGATCTCGTCCGATCTTGGAAGCTAAGCAGGGTTGGGCCTCATTAGTTCTTTGAAGGGA GACTGCCTGGGAATACCAGGTGCTGTAAGCTTTTTTCCAACCTGAAGCACTTTCATGCACGTACATTCAGTTCAGTGTCTTTACTTTGTTTTACTCCATCCC 612

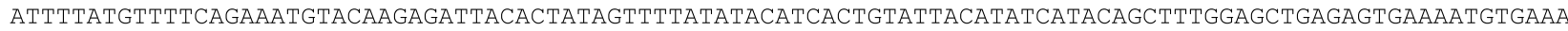
685

ATGCAGACCCTTTGAAACTTTGCATTATATAGCTCTCTGGAGCATATCTCGCTTACGGCCATACCAGCCTG

$\uparrow 5^{\prime}$ end of 5S rRNA gene

alignment of all clones is not shown, because there is a reduction of heterogeneity in each $5 \mathrm{~S}$ rDNA size class within a genome. A high nucleotide identity was observed among all 5S rDNA NTS-I clones and among all 5S rDNA NTS-II clones of each species, as a consequence of some particular homogenization mechanism(s), such as gene conversion or unequal crossing over (Dover 1986).

5S rDNA variations have been well characterized in several plants (Gottlob-McHugh et al. 1990; Cronn et al. 1996; Danna et al. 1996) and some animals, such as mouse (Suzuki et al. 1994) and Atlantic salmon and brown trout (Pendás et al. 1994). These polymorphism have been useful as genetic markers for distinguishing closely related species, subspecies, lines, and hybrids (Pendás et al. 1995) and for evolutionary analysis (Suzuki et al. 1994; Joffe et al. 1995; Udovicic et al. 1995; Cronn et al. 1996; Crisp et al. 1999; Baker et al. 2000). Variations in the 5S rDNA of the species analyzed were mainly observed in the NTSs, especially in those of the NTS-II class. Table 2 indicates the percent identity among the NTS-II sequences of the species studied. Brycon lundii, B. microlepis, and B. orbignyanus presented very similar NTS-II sequences, with a mean identity of $88 \%$, which could suggest a greater resemblance among these species. Brycon cephalus and Brycon sp. also seem to be more related to each other, since they presented very similar NTSII sequences (identity of 93\%). The NTS-II of Brycon insignis presented a mean sequence identity of $43 \%$ with the NTS-IIs of other species studied. The most distinct NTS-II was observed in B. brevicauda, which had a mean identity of $39 \%$ with those of the other species.

Despite the heterogeneity observed for the NTSs among Brycon spp., a relatively conserved sequence in the NTSs of approximately $120 \mathrm{bp}$ was found to be common to all the species. This sequence is represented by the NTS-I, which is very similar among all the species analyzed (Fig. 2; Table 2) and could be the ancestral 5S rDNA NTS of the Brycon group. This same conserved sequence of around $120 \mathrm{bp}$ also appears within the NTS-II sequence, although it is discontinuous, owing to several internal insertions-deletions that have occurred in each species (Fig. 2). This has led to a mean identity of only $46 \%$ among NTS-II sequences. In B. lundii, $B$. orbignyanus, and $B$. microlepis, the conserved sequence inside the NTS-II shows a deletion of $15 \mathrm{bp}$, when compared with the NTS-I sequence (Figs. $2 a-2 c$ ). The data observed may indicate a common origin for both NTS classes and also that the NTS-IIs are evolving faster in each species.

A conserved NTS $5^{\prime}$-end region (TTCCAACC) is another common feature of the two NTS classes (Fig. 2), suggesting a regulatory role, such as the control of transcription by RNA polymerase III (Nederby-Nielsen et al. 1993; Pendás et al. 1994; Suzuki et al. 1996). Moreover, as in the NTSs of other fish species (Felgenhauser et al. 1990; Pendás et al. 1994; Sajdak et al. 1998; Martins et al. 2000, 2001), a TATA-like sequence was observed upstream of the 5S rRNA gene in Brycon, at the -19 to -27 position (Fig. 2). Other TATA-like elements were also detected, although these re- 
Fig. 4. 5S rDNA FISH of metaphase chromosome spreads of B. lundii (a), B. microlepis (b), B. orbignyanus (c), B. cephalus (d), Brycon sp. (e), B. brevicauda $(f)$, and B. insignis $(g)$. Arrows indicate the 5S rDNA loci. Scale bar $=3 \mu \mathrm{m}$.
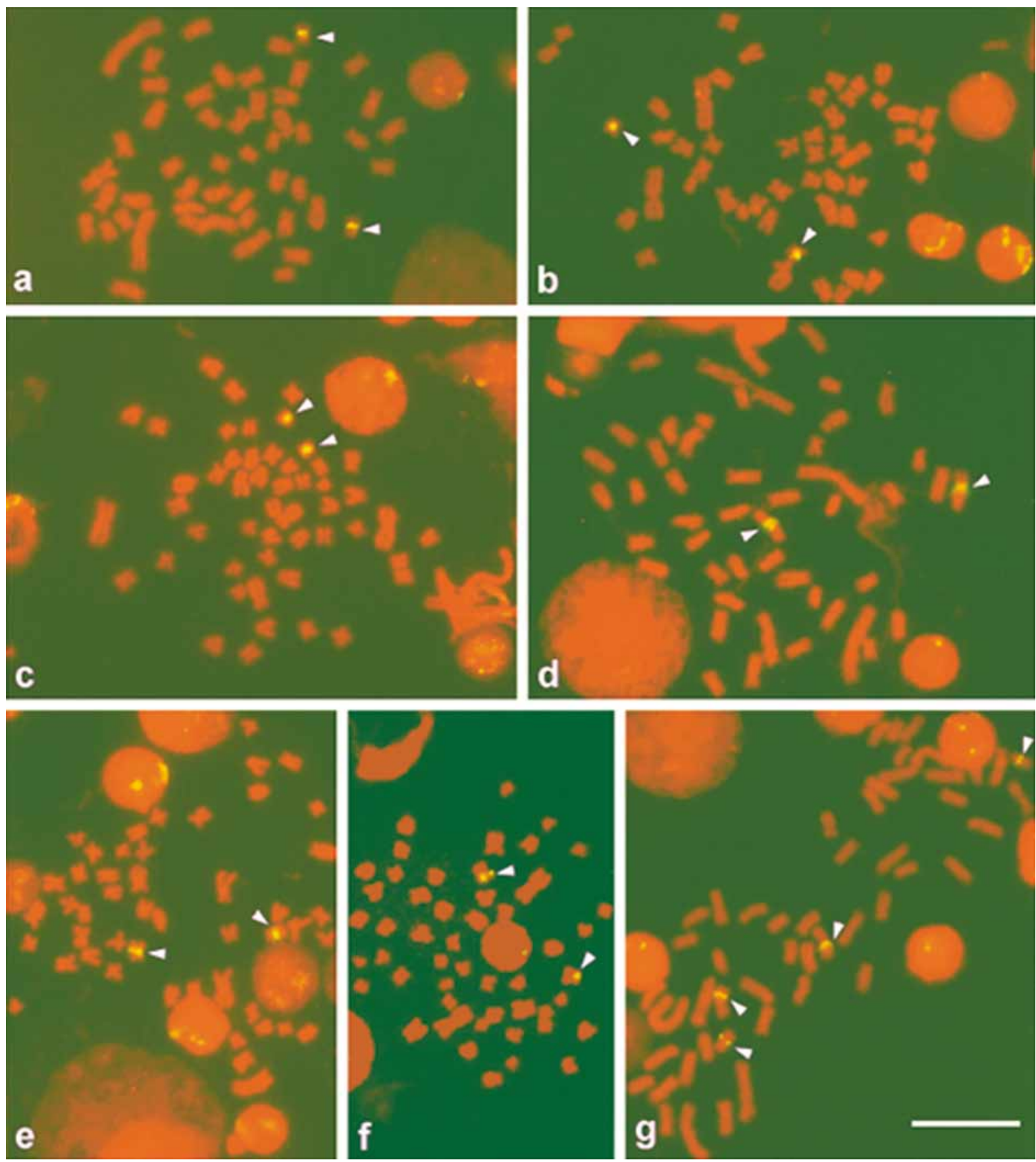

gions have a particular location in B. lundii, B.orbignyanus, and B. microlepis and a similar location in B. cephalus, Brycon sp., and B. brevicauda (Fig. 2).

Sequencing of $5 \mathrm{~S}$ rDNA dimers of $B$. cephalus and Brycon sp. (Fig. 3) determined the complete 5S rRNA gene nucleotide sequence of these two species. Within the limits of our analyses, we concluded that the repeated copies of the $5 \mathrm{~S}$ gene within each species were nearly identical (similarity of $99.14 \%$ in B. cephalus and $99.12 \%$ in Brycon sp.), with only a few differences that were mainly due to some base substitutions. As with 18S-28S rDNA and other tandemly repeated multigene families, the several repeats within the
$5 \mathrm{~S}$ arrays seem to retain a high degree of identity, owing to homogenizing forces, which are referred to as concerted evolution (Cronn et al. 1996).

Previous cytogenetic studies have shown that the diploid genome of different species of the genus Brycon consists of 50 chromosomes, and the karyotype formula of the seven species analyzed is already well established (AlmeidaToledo et al. 1996; Margarido and Galetti 1996). FISH revealed $5 \mathrm{~S}$ clusters located on two chromosomal sites that appear to be shared by the species analyzed. The $5 \mathrm{~S}$ rDNAbearing chromosomes in the karyotype of each species were identified by the chromosome pairing of several FISH meta- 
phases (data not shown). The first cluster was detected in the pericentromeric region of the long arm of a small submetacentric chromosome pair, and was observed in B. lundii (pair 23), B. microlepis (pair 22), and B. orbignyanus (pair 23) (Figs. 4a-4c). The second cluster, localized in the pericentromeric region of the long arm of two medium-sized submetacentric chromosomes corresponding to pair 15 , was detected in B. cephalus and Brycon sp. (Figs. $4 d$ and $4 e$ ). In $B$. brevicauda, the $5 \mathrm{~S}$ rDNA was visualized interstitially on the short arm of two medium-sized submetacentric chromosomes that seem to correspond to chromosome pair 15 of B. cephalus and Brycon sp. Brycon brevicauda was the only species that presented $5 \mathrm{~S}$ clusters on the short arm of a chromosome, and we suggest that this is the result of a pericentric inversion (Fig. 4f). In B. insignis, the $5 \mathrm{~S}$ rDNA was mapped to the pericentromeric region of the long arms of two chromosome pairs: a small submetacentric pair (pair 21) and a medium-sized submetacentric pair (pair 15) (Fig. 4g).

Although four hybridization signals were only seen on the chromosomes of $B$. insignis, the possibility that minor clusters of a few $5 \mathrm{~S}$ gene copies at other loci may have gone undetected using the FISH protocol cannot be eliminated, since the small size of these loci could impede their detection. An additional small fluorescent signal could be observed on a third chromosome in a few metaphases of $B$. lundii, B. orbignyanus, B. microlepis, B. cephalus, Brycon sp., and $B$. brevicauda (data not shown), which could indicate the occurrence of another $5 \mathrm{~S}$ cluster in these species. Multiple $5 \mathrm{~S}$ rDNA loci have been observed in amphibians (Vitelli et al. 1982; Schmid et al. 1987; Lucchini et al. 1993) and several fish species (Móran et al. 1996; Fujiwara et al. 1998; Murakami and Fujitani 1998; Martins and Galetti 1999; Martins et al. 2000).

Two main families of 5S rRNA genes that are expressed differently in oocytes and somatic cells have been described in amphibians (reviewed by Krämer 1985) and fishes (Komiya et al. 1986). Although these 5S rDNAs present a great sequence similarity in the coding region, their NTSs are very distinct. In Xenopus laevis, for example, the oocyte unit is about $750 \mathrm{bp}$ and includes the 120-bp gene, a NTS, and a pseudogene (Carrol and Brown 1976; Jacq et al. 1977), while the somatic unit has approximately $880 \mathrm{bp}$ and does not contain pseudogenes (Peterson et al. 1980). The two NTS classes (NTS-I and NTS-II) observed in Brycon spp. could be related to this dual system, which appears to represent paralogous copies of the $5 \mathrm{~S}$ unit that may have evolved in separate regions of the genome and could represent the two chromosomal loci observed in at least one of the species analyzed, B. insignis. Two 5S rDNA arrays with distinct chromosome locations were also identified in Leporinus spp. (Martins and Galetti 2001).

No detectable polymorphism, in either the size or intensity of the fluorescent signals, was observed between homologous chromosomes. Variations in the size of the hybridization signal were detected between the two $5 \mathrm{~S}$ rDNA-bearing chromosome pairs of B. insignis (Fig. $4 g$ ), characterizing a major and a minor locus. As an additional fluorescent signal could be observed on a third chromosome in a few metaphases of the other species analyzed, it is possible that all species also have two $5 \mathrm{~S}$ rDNA loci. In
B. lundii, B. microlepis, and B. orbignyanus, the major locus was detected by FISH in a small submetacentric chromosome pair, with a postulated minor locus on a medium-sized submetacentric pair. This pattern seems to be reversed for B. cephalus, Brycon sp., B. brevicauda, and B. insignis, with the major locus located in a medium-sized submetacentric chromosome pair and a postulated minor locus in a small submetacentric pair. The $5 \mathrm{~S}$ rDNA size polymorphism between chromosome pairs can be due to differences in the number of tandemly repeat ribosomal units (Warburton et al. 1976; Martins and Galetti 1999). Physical 5S rDNA chromosome mapping-B. lundii, $B$. orbignyanus, and $B$. microlepis present conspicuous $5 \mathrm{~S}$ clusters on a small submetacentric pair and B. cephalus and Brycon sp. present evident $5 \mathrm{~S}$ clusters on a medium-sized submetacentric pair-supports the presumptive relationships, based on NTS data, among these species.

Of note, all major 5S rDNA chromosome loci were coincident with heterochromatic regions that have been characterized previously by C-banding (Almeida-Toledo et al. 1996; Margarido and Galetti 1996). Similar association was also observed in salmonids (Fujiwara et al. 1998). While the major Brycon 5S rDNA loci were coincident with dark positive $\mathrm{C}$-bands, the minor ones were negative or weak for $\mathrm{C}$ banding. The presence of heterochromatin associated with 5S rDNA may facilitate an accumulation of these loci by unequal exchange (Warburton and Henderson 1979; Jhanwar et al. 1981).

In Brycon spp., the $5 \mathrm{~S}$ sites were not syntenic to the NORs. Silver nitrate staining (Margarido and Galetti 1996) and FISH with an $18 \mathrm{~S}$ rDNA probe (Wasko and Galetti 2000) showed two NORs in the end of the long arm of a unique large submetacentric pair in all seven species analyzed. Such disjunct chromosome locations for a NOR and 5S rDNA loci have already been reported for Anguilla anguilla (Martínez et al. 1996), Coregonus artedti and C. zenithicus (Sajdak et al. 1998), genus Leporinus (Martins and Galetti 1999), genus Schizodon (Martins and Galetti 2000), Hoplias malabaricus (Born and Bertollo 2000), and Oreochromis niloticus (Martins et al. 2000) and is, by far, the most frequent condition observed in vertebrates (Lucchini et al. 1993; Drouin and Moniz de Sá 1995; Suzuki et al. 1996).

Not only have 5S rDNA nucleotide sequencing and chromosomal localization permitted the characterization of seven Brycon spp. and inferred a higher similarity among some of them, but two distinct 5S rDNA NTS classes have also been detected. The data obtained indicate that the 5S rDNA can serve as a suitable genetic marker for evolutionary studies and for the genetic identification of related species in the genus Brycon.

\section{Acknowledgements}

The authors thank the anonymous reviewers that contributed to improving the final version of the manuscript. A.P.W. and C.M. were supported by fellowships from Fundação de Amparo à Pesquisa do Estado de São Paulo (FAPESP) and the United Nations Scientific, Educational, and Cultural Organization. This work was also supported by a grant from the Natural Sciences and Engineering Research Council of 
Canada to J.M.W. and by Conselho Nacional de Desenvolvimento Científico e Tecnológico (CNPq) and FAPESP to P.M.G., Jr.

\section{References}

Almeida-Toledo, L.F., Bigoni, A.P., Bernardino, G., Foresti, F., and Toledo-Filho, A.S. 1996. Karyotype and NOR conservatism with heterochromatin reorganization in Neotropical bryconids. Caryologia, 49: 35-43.

Altschul, S.F., Gish, W., Miller, W., Myers, E.W., and Lipman, D.J. 1990. Basic local alignment search tool. J. Mol. Biol. 215: 403410.

Baker, W.J., Hedderson, T.A., and Dransfield, J. 2000. Molecular phylogenetics of Calamus (Palmae) and related rattan genera based on 5S nrDNA spacer sequence data. Mol. Phylogenet. Evol. 14: 218-231.

Bertollo, L.A.C., Takahashi, C.S., and Moreira Filho, O. 1978. Cytotaxonomic consideration on Hoplias lacerdae (Pisces, Erythrinidae). Braz. J. Genet. 1: 103-120.

Born, G.G., and Bertollo, L.A.C. 2000. An XX/XY sex chromosome system in a fish species, Hoplias malabaricus, with a polymorphic NOR bearing X chromosome. Chromosome Res. 8: $111-118$.

Braga, R.A. 1982. Depleção aparente do matrinxã, Brycon hilarii, em pesqueiros do Rio São Francisco. Bol. Tec. Dep. Obras Contra Secas (Braz.), 40: 175-180.

Carrol, D., and Brown, D.D. 1976. Adjacent repeating units of Xenopus laevis 5S DNA can be heterogeneous in length. Cell, 7: 477-486.

Crisp, M.D., Appels, R., Smith, F.M., and Keys, W.M.S. 1999. Phylogenetic evaluation of 5S ribosomal RNA gene and spacer in the Callistachys group (Fabacea: Mirbelieae). Plant Syst. Evol. 218: 33-42.

Cronn, R.C., Zhao, X., Paterson, A.H., and Wendel, J.F. 1996. Polymorphism and concerted evolution in a tandemly repeated gene family: 5S ribosomal DNA in diploid and allopolyploid cottons. J. Mol. Evol. 42: 685-705.

Danna, K.J., Workman, R., Coryell, V., and Keim, P. 1996. 5S rRNA genes in tribe Phaseoleae: array size, number, and dynamics. Genome, 39: 445-455.

Dover, G.A. 1986. Linkage disequilibrium and molecular drive in the rDNA gene family. Genetics, 122: 249-252.

Drouin, G., and Moniz de Sá, M. 1995. The concerted evolution of $5 \mathrm{~S}$ ribosomal genes linked to the repeat units of other multigene families. Mol. Biol. Evol. 12: 481-493.

Felgenhauser, P., Sedman, J., and Shostak, N. 1990. The 5'-flanking sequence of the loach oocyte 5S rRNA gene contains a signal for effective transcription. Gene (Amst.), 90: 243-248.

Fenocchio, A.S., Venere, P.C., Cesar, A.C.G., Dias, A.L., and Bertollo, L.A.C. 1991. Short term culture from solid tissues of fishes. Caryologia, 44: 161-166.

Fujiwara, A., Abe, S., Yamaha, E., Yamazaki, F., and Yoshida, M.C. 1998. Chromosomal localization and heterochromatin association of ribosomal RNA gene loci and silver stained nucleolar organizer regions in salmonid fishes. Chromosome Res. 6: 463-471.

Gottlob-McHugh, S.G., Levesque, M., MacKenzie, K., Olson, M., Yarosh, O., and Johnson, D.A. 1990. Organization of the 5S rRNA genes in the soybean Glycine $\max (\mathrm{L}$.) Merril and conservation of the $5 \mathrm{~S}$ rDNA repeat structure in higher plants. Genome, 33: 486-494.

Howes, G.J. 1982. Review of the genus Brycon (Teleostei, Characoidei). Bull. Am. Mus. Nat. Hist. (Zool.), 43: 1-47.
Jacq, C., Miller, J.R., and Brownlee, G.G. 1977. A pseudogene structure in 5S DNA of Xenopus laevis. Cell, 12: 109-120.

Jhanwar, S.C., Prensky, W., and Chaganti, R.S.K. 1981. Localization and metabolic activity of ribosomal genes in Chinese hamster meiotic and mitotic chromosomes. Cytogenet. Cell Genet. 30: $39-46$.

Joffe, B.I., Valiejo-Roman, K.M., Birstein, V.Y., and Troitsky, A.V. 1995. 5S rRNA sequences of 12 species of flatworms: implications for the phylogeny of the Platyhelminthes. Hydrobiologia, 305: 37-43.

Komiya, H., and Takemura, S. 1979. Nucleotide sequence of 5S ribosomal RNA from rainbow trout (Salmo gairdnerii) liver. J. Biochem. 86: 1067-1080.

Komiya, H., Hasegawa, M., and Takemura, S. 1986. Differentiation of oocyte- and somatic-type 5S rRNAs in animals. J. Biochem. 100: $369-374$.

Krämer, A. 1985. 5S ribosomal gene transcription during Xenopus oogenesis. In Developmental biology. A comprehensive synthesis. Vol. 1. Edited by L.W. Browder. Plenum Press, New York. pp. 431-451.

Leah, R., Frederiksen, S., Engberg, J., and Sorensen, P.D. 1990. Nucleotide sequence of a mouse 5S rRNA variant gene. Nucleic Acids. Res. 18: 7441.

Long, E.O., and David, I.D. 1980. Repeated genes in eukaryotes. Annu. Rev. Biochem. 49: 727-764.

Lucchini, S., Nardi, I., Barsacchi, G., Batistoni, R., and Andronico, F. 1993. Molecular cytogenetics of the ribosomal $(18 \mathrm{~S}+28 \mathrm{~S}$ and 5S) DNA loci in primitive and advanced urodele amphibians. Genome, 36: 762-773.

Margarido, V.P., and Galetti, P.M., Jr. 1996. Chromosome studies in fish of the genus Brycon (Characiformes, Characidae, Bryconinae). Cytobios, 85: 219-228.

Martínez, J.L., Móran, P., Garcia-Vásquez, E., and Pendás, A.M. 1996. Chromosomal localization of the major and minor $5 \mathrm{~S}$ rRNA genes in the European eel (Anguilla anguilla). Cytogenet. Cell Genet. 73: 149-152.

Martins, C., and Galetti, P.M., Jr. 1999. Chromosomal localization of 5S rDNA genes in Leporinus fish (Anostomidae, Characiformes). Chromosome Res. 7: 363-367.

Martins, C., and Galetti, P.M., Jr. 2000. Conservative distribution of 5S rDNA loci in Schizodon (Pisces, Anostomidae) chromosomes. Chromosome Res. 8: 353-355.

Martins, C., and Galetti, P.M., Jr. 2001. Organization of 5S rDNA in Leporinus fish species: two different genomic locations are characterized by distinct nontranscribed spacers. Genome, 44: 903-910.

Martins, C., Wasko, A.P., and Wright, J.M. 2000. Nucleotide sequence of $5 \mathrm{~S}$ rDNA and localization of the ribosomal RNA genes to metaphase chromosomes of the tilapiine cichlid fish, Oreochromis niloticus. Hereditas, 133: 39-46.

Móran, P., Martínez, J.L., Garcia-Vásquez, E., and Pendás, A.M. 1996. Sex linkage of 5S rDNA in rainbow trout (Oncorhynchus mykiss). Cytogenet. Cell Genet. 75: 145-150.

Murakami, M., and Fujitani, H. 1998. Characterization of repetitive DNA sequences carrying 5S rDNA of the triploid ginbuna (Japanese silver crucian carp, Carassius auratus langsdorfi). Genes Genet. Syst. 73: 9-20.

Nederby-Nielsen, J., Hallenberg, C., Frederiksen, S., Sorensen, P.D., and Lomholt, B. 1993. Transcription of human 5S rRNA genes is influenced by an upstream DNA sequence. Nucleic Acids Res. 26: 3631-3636.

Nelson, D.W., and Honda, B.M. 1985. Genes coding for 5S ribosomal RNA of the nematode Caenorhabditis elegans. Gene (Amst.), 38: 245-251. 
Pendás, A.M., Móran, P., Freije, J.P., and Garcia-Vásquez, E. 1994. Chromosomal location and nucleotide sequence of two tandem repeats of the Atlantic salmon 5S rDNA. Cytogenet. Cell Genet. 67: 31-36.

Pendás, A.M., Móran, P., Martínez, J.L., and Garcia-Vásquez, E. 1995. Applications of 5S rDNA in Atlantic salmon, brown trout, and in Atlantic salmon $\times$ brown trout hybrid identification. Mol. Ecol. 4: 275-276.

Peterson, R.C., Doering, J.L., and Brown, D.D. 1980. Characterization of two Xenopus somatic 5S DNAs and one minor oocytespecific 5S DNA. Cell, 20: 131-141.

Saiki, R.K., Gefland, D.H., Stoffel, S., Scharf, S.J., Higuchi, R., Horn, G.T., Mullis, K.B., and Erlich, H.A. 1988. Primer-directed enzymatic amplification of DNA with a thermostable DNApolymerase. Science (Washington, D.C.), 239: 487-491.

Sajdak, S.L., Reed, K.M., and Phillips, R.B. 1998. Intraindividual and interspecies variation in the $5 \mathrm{~S}$ rDNA of coregonid fish. J. Mol. Evol. 46: 680-688.

Sambrook, J., Fritsch, E.F., and Maniatis, T. 1989. Molecular cloning: a laboratory manual. Cold Spring Harbor Laboratory Press, Cold Spring Harbour, New York.

Schmid, M., Vitelli, L., and Batistoni, R. 1987. Chromosome banding in Amphibia. IV. Constitutive heterochromatin, nucleolus organizers, $18 \mathrm{~S}+28 \mathrm{~S}$ and $5 \mathrm{~S}$ ribosomal RNA genes in Ascaphidae, Pipidae, Discoglossidae and Pelobatidae. Chromosoma (Berlin), 95: 271-284.

Suzuki, H., Moriwaki, K., and Sakurai, S. 1994. Sequences and evolutionary analysis of mouse 5S rDNAs. Mol. Biol. Evol. 11: 704-710.

Suzuki, H., Sakurai, S., and Matsuda, Y. 1996. Rat rDNA spacer sequences and chromosomal assignment of the genes to the extreme terminal region of chromosome 19. Cytogenet. Cell Genet. 72: 1-4.

Thompson, J.D., Higgins, D.G., and Gibson, T.J. 1994. Clustal W: improving the sensitivity of progressive multiple sequence alignment through sequence weighting, position-specific gap penalties and weight matrix choice. Nucleic Acids Res. 22: 4673-4680.

Udovicic, F., McFadden, G.L., and Ladiges, P.Y. 1995. Phylogeny of Eucaliptus and Angophora based on 5S rDNA spacer sequence data. Mol. Phylogenet. Evol. 4: 247-256.

Vitelli, L., Batistoni, R., Andronico, F., Nardi, I., and BarsacchiPilone, G. 1982. Chromosomal localization of $18 \mathrm{~S}+28 \mathrm{~S}$ and $5 \mathrm{~S}$ ribosomal RNA genes in evolutionary divergent anuran amphibians. Chromosoma (Berlin), 84: 475-491.

Warburton, D., and Henderson, A.S. 1979. Sequential silver staining and hybridization in situ of nucleolus organizer regions in human cells. Cytogenet. Cell Genet. 24: 168-175.

Warburton, D., Atwood, K.C., and Henderson, A. 1976. Variation in the number of genes for RNA among human acrocentric chromosomes: correlation with frequency of satellite association. Cytogenet. Cell Genet. 17: 221-230.

Wasko, A.P., and Galetti, P.M., Jr. 2000. Mapping 18S ribosomal genes in fish of the genus Brycon (Characidae) by fluorescence in situ hybridization (FISH). Genet. Mol. Biol. 23: 135-138. 